\title{
pTO Prostate Cancer: Predictive Clinicopathologic Features in an American Population
}

\author{
Matthew J. Bream ${ }^{\mathrm{a}} \quad$ Laila Dahmoush $^{\mathrm{b}}$ James A. Brown ${ }^{\mathrm{a}}$ \\ Departments of a Urology and ' $P$ Pathology, University of lowa, lowa City, lowa, USA
}

\section{Key Words}

Prostate cancer • Biopsy • Cancer staging

\begin{abstract}
Introduction: The pT0 stage of prostate cancer describes the radical prostatectomy (RP) specimen where no cancer can be identified. Given known racial and geographic differences in prostate cancer incidence and survival, we reviewed our experience with pT0 disease to determine applicability of these predictive features in an American population. Materials and Methods: A retrospective chart review was conducted for all RPs at one state tertiary care institution during a 20year period (1991-2011). Clinicopathologic features of pT0 patients were collected and their relevant pathologic material re-reviewed. Results: Of a total of 1,635 RPs performed, $4(0.2 \%)$ not receiving neoadjuvant therapy or other prior prostate surgeries were stage pT0. Biopsies from 3 of 4 patients were re-evaluated and confirmed a small focus, $<1 \%$ of tissue, of Gleason score 3+3 adenocarcinoma; a fourth was not available for re-review. Our re-review of the RP slides identified small foci of cancer in two of the four, thus yielding a final true pT0 incidence of $0.1 \%$. Preoperative prostate specific antigen ranged from 4.4 to $7.4 \mathrm{ng} / \mathrm{ml}$, clinical stages were all T1c, and there was no evidence of recurrence at 3 months to 10 years of follow-up. Conclusions: Stage pT0 prostate cancer is very uncommon, occurring with an incidence of $0.1 \%$, and in our experience occurs only in clinical T1c patients with pre-biopsy prostate specific antigen $<7.5$ $\mathrm{ng} / \mathrm{ml}$, with Gleason score $3+3$ adenocarcinoma comprising $<1 \%, 1 \mathrm{~mm}$ of a single core biopsy, a stricter threshold than that seen in non-American populations.
\end{abstract}

Copyright $\odot 2013$ S. Karger AG, Basel

\section{KARGER}

Fax +4161306 1234

E-Mail karger@karger.ch

www.karger.com
(C) 2013 S. Karger AG, Basel

1015-9770/13/0071-0014\$26.00/0

Accessible online at:

www.karger.com/cur

\section{Introduction}

Stage pT0 prostate cancer describes prostate cancer that cannot be identified in a radical prostatectomy (RP) specimen that has been removed for biopsy-proven prostate cancer. This stage was first described by Goldstein et al. in 1995 [1], and is an uncommon occurrence with a recent literature review citing an incidence of $0.4 \%$ of all RPs [2]. Prostate specific antigen (PSA) recurrence or disease progression in pT0 cases has not been seen in published series [24], with the exception of 6 men with PSA recurrence identified in a cohort of pT0 patients diagnosed and treated at U.S. military hospitals [5]. While uncommon, this occurrence is important because it presents a difficult situation for the patient, surgeon, and pathologist, both clinically and medicolegally. Similar to the ypT0 stage are those patients who have undergone neoadjuvant hormonal or radiation therapy prior to RP of a subsequent "cancer-free" prostate; these represent stage pT0. Additionally, the pT0 stage excludes patients whose prostate cancer diagnosis was an incidental finding.

It would be useful to identify clinical and pathologic factors that can preoperatively predict who would be stage pT0 after prostatectomy. To date, there are 2 studies that have compared pT0 patients to controls in an effort to identify these characteristics (table 1) $[6,7]$. These studies report pT0 incidences of 0.5 and $1.3 \%$, and cite biopsy Gleason scores 6 or less, 12 positive biopsies, biopsy tumor length $2 \mathrm{~mm}$, and prostate size $>60 \mathrm{~g}$ or $>30 \mathrm{~cm}^{3}$ as being significantly more common in pT0 patients, but preoperative PSA was not shown to be significantly different. While these characteristics are more 
Table 1. Prior studies citing predictive clinicopathologic features more common in pT0 compared to pT+ control populations

\begin{tabular}{|c|c|c|c|c|c|c|c|}
\hline Study & Population & Incidence & Patients,n & Gleason score & $\begin{array}{l}\text { No. positive } \\
\text { biopsy cores }\end{array}$ & $\begin{array}{l}\text { Tumor length } \\
\text { on biopsy }\end{array}$ & Prostate size \\
\hline Park et al. [4] & Korean & $1.3 \%$ & 702 & $6^{*}$ & $2 *$ & $2 \mathrm{~mm}^{*}$ & $>30 \mathrm{~cm}^{3 *}$ \\
\hline Present study & North American & $0.2 \%$ & 1,635 & $6^{\mathrm{a}}$ & $1^{\mathrm{a}}$ & $1 \mathrm{~mm}^{\mathrm{a}}$ & $>44 \mathrm{~g}^{\mathrm{a}}$ \\
\hline
\end{tabular}

Threshold values for $\mathrm{pT} 0$ cases; * $\mathrm{p}<0.05$ when compared to $\mathrm{pT}+$ control populations.

Table 2. Clinicopathologic features of the four pT0 patients from the present study

\begin{tabular}{|c|c|c|c|c|c|c|c|c|}
\hline Year (case) & Age, year & Stage & PSA, ng/mL & $\begin{array}{l}\text { Original biopsy } \\
\text { pathology }\end{array}$ & Biopsy re-review & $\begin{array}{l}\text { Original RP } \\
\text { pathology }\end{array}$ & RP re-review & Disease course \\
\hline $1997(1)$ & 67 & $\mathrm{~T} 1 \mathrm{c}$ & 5.82 & $\begin{array}{l}\text { single focus } \\
\text { of Gleason } \\
3+3 \mathrm{CaP} \text {; no } \\
\text { additional } \\
\text { information on } \\
\text { number of cores } \\
\text { involved }\end{array}$ & not available & $\begin{array}{l}\text { no CaP; } \\
56 \mathrm{~g}\end{array}$ & $\begin{array}{l}\text { agree with } \\
\text { original inter- } \\
\text { pretation }\end{array}$ & $\begin{array}{l}\text { no clinical or PSA ev- } \\
\text { idence for recurrence; } \\
10 \text { years of follow-up }\end{array}$ \\
\hline 2003 (2) & 68 & $\mathrm{~T} 1 \mathrm{c}$ & 7.4 & $\begin{array}{l}\text { single focus of } \\
\text { Gleason } 3+3 \\
\text { CaP involving } \\
<5 \% \text { of tissue }\end{array}$ & $\begin{array}{l}6 \text { glands of Glea- } \\
\text { son } 3+3 \mathrm{CaP} \\
<1 \% \text { of a single } \\
\text { core }\end{array}$ & $\begin{array}{l}\text { no CaP; } \\
\text { multifocal } \\
\text { high-grade } \\
\text { PIN; } 65 \mathrm{~g}\end{array}$ & $\begin{array}{l}\text { agree with } \\
\text { original inter- } \\
\text { pretation }\end{array}$ & $\begin{array}{l}\text { idence for recurrence; } \\
3 \text { years of follow-up } \\
\text { no clinical or PSA ev- } \\
\text { idence for recurrence; }\end{array}$ \\
\hline 2007 (3) & 67 & $\mathrm{~T} 1 \mathrm{c}$ & 6.7 & $\begin{array}{l}\text { single focus of } \\
\text { Gleason } 3+3 \\
\text { CaP involving } \\
5 \% \text { of tissue }\end{array}$ & $\begin{array}{l}12 \text { glands of } \\
\text { Gleason } 3+3 \\
\mathrm{CaP},<1 \% \text { of a } \\
\text { single core }\end{array}$ & $\begin{array}{l}\text { no CaP; } \\
\text { high-grade } \\
\text { PIN; } 77 \mathrm{~g}\end{array}$ & $\begin{array}{l}\text { small focus of } \\
\text { Gleason } 3+3 \\
\text { CaP original- } \\
\text { ly interpreted } \\
\text { as high-grade } \\
\text { PIN }\end{array}$ & $\begin{array}{l}2 \text { years of follow-up } \\
\text { no clinical or PSA } \\
\text { evidence for recur- } \\
\text { rence; } 3 \text { months of }\end{array}$ \\
\hline $2010(4)$ & 61 & $\mathrm{~T} 1 \mathrm{c}$ & 4.4 & $\begin{array}{l}\text { single focus of } \\
\text { Gleason } 3+3 \\
\text { CaP }(6 \text { glands } \\
\text { at one end of } \\
1 \text { of } 4 \text { core } \\
\text { biopsies, }<5 \% \\
\text { of tissue) }\end{array}$ & $\begin{array}{l}6 \text { glands of Glea- } \\
\text { son } 3+3 \mathrm{CaP}, \\
<1 \% \text { of a single } \\
\text { core }\end{array}$ & $\begin{array}{l}\text { no CaP; } \\
44 \mathrm{~g}\end{array}$ & $\begin{array}{l}\text { small focus of } \\
\text { Gleason } 3+3 \\
\text { CaP not origi- } \\
\text { nally seen }\end{array}$ & follow-up \\
\hline
\end{tabular}

common in pT0, these and other studies report pT0 cases in patients with up to Gleason 7 disease, 4 positive cores, or $18 \mathrm{~mm}$ of cancer on core biopsy [6-8], thus highlighting the challenge in identifying a true clinicopathologic threshold above which pT0 disease will not be seen.
Further, these studies were done in Korean and French populations, and to our knowledge there have been no similar studies performed in a North American population. Geographic and racial differences in prostate cancer incidence and mortality have been previously identified 
[9], and it is thus unclear whether these geographic and racial differences, or perhaps variations in pathologic handling of prostatectomy specimens, have any impact on the pT0 incidence or predictive clinicopathologic characteristics. The aim in reviewing our experience with the pT0 stage is to report our incidence and to confirm whether the predictive clinicopathologic thresholds cited in prior Korean and French studies are accurate in a North American population.

\section{Materials and Methods}

Institutional Review Board approval was obtained for a retrospective review of all RPs performed at our tertiary care state academic institution during the 20-year period from 1991 to 2011. Pathology reports for all RPs were read, and those that did not document adenocarcinoma were further reviewed. Only patients with biopsy proven prostate cancer identified due to clinical concern for prostate cancer were included in this study. Patients whose prostate cancer was an incidental finding, i.e. identified during transurethral resection of the prostate or during cystoprostatectomy for other diagnoses, were excluded. Data obtained from the medical record included patient demographics, preoperative clinical staging with PSA levels, all pathology reports, clinical history specifically including any neoadjuvant therapy, and postoperative clinical follow-up including PSA levels. All available pathology slides, both from the biopsies and the RP specimens, were reviewed by a dedicated urologic pathologist (L.D.) with more than 10 years of experience providing consultation on urologic specimens. No new tissue preparations, special stains, or additional slides were made from the existing paraffin tissue blocks.

\section{Results}

A total of 1,635 RPs were performed for biopsy-proven prostate cancer. Of these, 6 patients with no residual cancer found at RP, who had undergone neoadjuvant therapy (ypT0), were excluded. Neoadjuvant therapy for all six included initial bicalutamide followed by leuprolide injections for a mean duration of 5 months (range 211 months). Biopsy and RP slides from these ypT0 patients were not re-reviewed for this study.

Four patients staged as pT0 $(0.2 \%$ of all RP) who did not undergo neoadjuvant therapy were identified (table 2 ). All four were clinical stage T1c with mean preoperative PSA of $6.1 \mathrm{ng} / \mathrm{ml}$ (range 4.4-7.4 ng/ml). In each case, the original biopsies documented a single focus of Gleason $3+3=6$ adenocarcinoma (fig. 1). Upon re-review for this study, the biopsies for each case were confirmed to have Gleason $3+3=6$ adenocarcinoma present in 1 of 10,1 of 8 , and 1 of 6 cores for patients 2,3 , and 4 ,

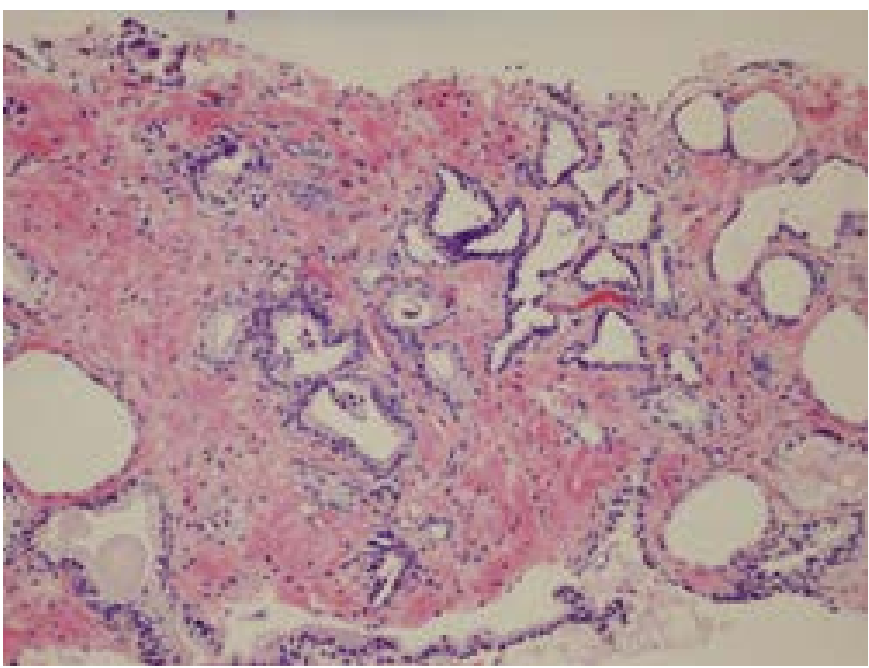

Fig. 1. Photomicrograph of pT0 patient's prostate biopsy showing focal Gleason pattern 3 adenocarcinoma.

respectively. The amount of adenocarcinoma (estimated from the linear extent of cancerous glands and total core length) was determined to be $<1 \%$ of the positive core in each case, with each being $<1 \mathrm{~mm}$. The biopsy slides for patient 1 had been discarded by the referring institution given that they had exceeded the requisite retention time of 10 years required by the Clinical Laboratory Improvement Amendment (CLIA), and thus were not available for re-review.

These 4 pT0 patients all underwent RP within 4 months after biopsies were obtained. The removed prostate glands had an average weight of $61 \mathrm{~g}$ (range 44-77 g). All 4 RP specimens were completely paraffin-embedded after the initial sampling and did not identify cancer. Deeper step-sections were done by the original reviewing pathologist only on select blocks with suspicious glands, and K903 immunohistochemical stains were selectively used in cases 1 and 2. Some atypical glands were seen, but no definitive adenocarcinoma was documented in the original interpretations for each case.

Re-review of these 4 RPs for the purpose of this study, however, yielded different interpretations in cases 3 and 4 (table 2). In case 3 there was a small focus of Gleason pattern 3 adenocarcinoma that was originally interpreted as high-grade prostatic intraepithelial neoplasia (PIN). In case 4 there was also a small yet conspicuous focus of 
Gleason pattern 3 adenocarcinoma that originally went unnoticed. These findings would have made the staging pT2a rather than pT0 for these 2 cases, and thus would have resulted in an overall pT0 incidence of $0.1 \%$ ( 2 of $1,635)$.

\section{Discussion}

A limitation of this study is the low number of pT0 cases identified, four, as compared to other studies that looked specifically at pT0 as well [36]. Our $0.1 \%$ incidence is the lowest reported to date. A second limitation is that 1 patient had biopsy slides that were not available for re-review. However, our primary goal was to determine if previously published predictive factors applied to our North American population as the other studies had been performed on Korean and French populations.

Stage pT0 prostate cancer is uncommon, and our institution's experience observes that it may be even less common than previously believed, at a North American tertiary care facility, with an incidence of $0.2 \%$. Additionally, our study further demonstrates the importance of prostatectomy re-review by an additional pathologist, as the incidence was adjusted downward to $0.1 \%$ after finding small foci of cancer at re-review. This trend has been demonstrated in prior studies as well, with some employing specific protocol for additional sampling of the posterior lobes, flipping the paraffin blocks and immunostaining $[10,11]$. Given the retrospective nature of our review, we were unable to employ these additional sampling techniques in a systematic fashion. It is unclear why our study identified a much lower pT0 rate as compared to prior studies where 0.5 to $1.3 \%$ of prostatectomy specimens were deemed pT0. A possible explanation includes inherently greater tumor volume/more aggressive disease in our patients limiting the cohort of patients with very low volume Gleason 6 disease.

The preoperative clinicopathologic features of low Gleason score ( 6), low number of positive core biopsies (only 1 or 2), and low length of cancer on biopsy ( 2 $\mathrm{mm}$ ) cited in previous studies to predict pT0 $[6,7]$ were each met by the four pT0 cases in our study. Importantly, however, our data demonstrate that the even stricter criteria of a single positive biopsy core containing less $1 \mathrm{~mm}$ tumor length of cancer can be applied as the threshold above which pT0 disease was never seen in our North American population.

In each of our 4 pT0 cases, the cancer biopsy diagnosis was made on a very small amount $(<1 \%,<1 \mathrm{~mm})$ of cancer with a Gleason score of 6 (never 7) in a man with clinical T1c disease and a PSA $<7.5 \mathrm{ng} / \mathrm{ml}$. Not finding identifiable residual cancer in the resected prostate and no evidence of PSA recurrence affirms that men with these clinicopathologic features do have low-risk disease and are the most optimal candidates for surveillance rather than treatment.

A final point is the topic of pathologic sampling. Pathologic evaluation is inherently subject to sampling bias, and pathology reports are best understood and applied in this light. Each of our prostatectomy specimens was very liberally sampled, yielding upwards of 80 slides per case, yet this is only a fraction of the several thousand slides it would take to look at each $4 \mu \mathrm{m}$ slice of tissue [12]. If this were to be done, at some point pathologist fatigue would most certainly contribute to error, not to mention come at an exorbitant cost.

\section{Conclusions}

Our study demonstrates that the incidence of pT0 prostate cancer in a North American population may be lower than previously reported $(0.2 \%$ rather than 0.4 $1.3 \%)$. Re-review of pT0 cases will identify a tiny focus of Gleason 3 prostate cancer in approximately half of specimens leading to a final true pT0 incidence rate of $0.1 \%$. We observed a potentially clinically useful and narrower clinicopathologic threshold (PSA $<7.5 \mathrm{ng} / \mathrm{ml}$, clinical T1c disease, Gleason score 6 , solitary core with cancer occupying $<1 \mathrm{~mm}$ or $<1 \%$ of tissue) for counseling patients in terms of pT0 risk. Patients with very minimal biopsy cancer below this threshold are likely better served with surveillance unless repeat biopsy demonstrates more concerning findings. 


\section{References}

1 Goldstein NS, Begin LR, Grody WW, Novak JM, Qian J, Bostwick DG: Minimal or no cancer in radical prostatectomy specimens. Report of 13 cases of the "vanishing cancer phenomenon". Am J Surg Pathol 1995;19: 1002-1009.

$\checkmark 2$ Gross JL, Masterson TA, Cheng L, Johnstone PA: pT0 prostate cancer after radical prostatectomy. J Surg Oncol 2010;102:331-333.

-3 Bostwick DG, Bostwick KC: "Vanishing" prostate cancer in radical prostatectomy specimens: incidence and long-term follow-up in 38 cases. BJU Int 2004;94:57-58.

-4 Herkommer K, Kuefer R, Gschwend J, Hautmann RE, Volkmer BG: Pathological T0 prostate cancer without neoadjuvant therapy: clinical presentation and follow-up. Eur Urol 2004;45:36-41.
5 Gurski JL, Chen Y, Zhao J, Peterson AC, Brand TC: pT0 is not benign disease: there is risk of progression in patients with no cancer in radical prostatectomy specimens (abstract 584). J Urol 2009;181(4 suppl):208.

6 Descazeaud A, Zerbib M, Flam T, Vieillefond A, Debré B, Peyromaure M: Can pT0 stage of prostate cancer be predicted before radical prostatectomy? Eur Urol 2006;50:12481253.

7 Park J, Jeong IG, Bang JK, Cho YM, Ro JY, Hong JH, Ahn H, Kim CS: Preoperative clinical and pathological characteristics of pT0 prostate cancer in radical prostatectomy. Korean J Urol 2010;51:386-390.

>8 Bessede T, Soulie M, Mottet N, Rebillard X, Peyromaure M, Ravery V, Salomon L; Cancerology Committee of the French Urological Association: Stage pT0 after radical prostatectomy with previous positive biopsy sets: a multicenter study. J Urol 2010;183:958-962.
9 Stanford JL, Stephenson RA, Coyle LM: Prostate Cancer Trends 19731995, SEER Program, National Cancer Institute. NIH Pub. No 99-4543. Bethesda, MD, 1999.

10 Mazzucchelli R, Barbisan F, Tagliabracci A, Lopez-Beltran A, Cheng L, Scarpelli M, Montironi R: Search for residual prostate cancer on pT0 radical prostatectomy after positive biopsy. Virchows Arch 2007;450:371-378.

11 Duffield AS, Epstein JI: Detection of cancer in radical prostatectomy specimens with no residual carcinoma in the initial review of slides. Am J Surg Pathol 2009;33:120-125.

12 Humphrey PA: Complete histologic serial sectioning of a prostate gland with adenocarcinoma. Am J Surg Pathol 1993;17:468-472. 